\title{
PENGARUH WAKTU BELAJAR DAN MINAT BELAJAR TERHADAP HASIL BELAJAR MATEMATIKA
}

\author{
INDAH LESTARI \\ ndanandy99yahoo.co.id \\ 085697267825 \\ Program Studi pendidikan Matematika, Fakultas Teknik, Matematika dan IPA \\ Universitas Indraprasta PGRI
}

\begin{abstract}
Abstrak. Tujuan dari penelitian ini adalah untuk mengetahui pengaruh waktu belajar terhadap hasil belajar matematika. Mengetahui pengaruh minat belajar terhadap hasil belajar matematika. Mengetahui pengaruh interaksi antara waktu belajar dan minat belajar terhadap hasil belajar matematika. Metode penelitian yang digunakan adalah metode survey expose facto. Sampel yang berjumlah 52 orang dipilih secara random dari seluruh siswa di SMP negeri di kecamatan Cipayung. Pengumpulan data dilakukan dengan pemberian soal tes tertulis untuk mengukur variabel yang diteliti. Analisis data dengan menggunakan metode statistic deskriptif dan anova 2 arah. Hasil penelitian menunjukkan terdapat pengaruh yang signifikan waktu belajar terhadap hasil belajar matematika dengan nilai sig $=0,038$. Terdapat pengaruh yang signifikan minat belajar terhadap hasil belajar matematika dengan nilai sig $=0,00$. Tidak terdapat pengaruh interaksi yang signifikan antara waktu belajar dan minat belajar terhadap hasil belajar matematika dengan nilai sig $=0,422$
\end{abstract}

Kata Kunci: Waktu Belajar, Minat Belajar, Hasil belajar Matematika

\begin{abstract}
The purpose of this research was to the determinate the effect of study time on mathematics learning outcomes. To determinate the effect of interest in learning the mathematics learning outcomes. To determinate the effect of the interaction between study time and interest in learning the mathematics learning outcomes. Methods of research used survey methods expose facto. Sample of 52 people selected at random from all junior high school students in the district Cipayung. Data collection is done by giving a written test questions to measure variables studied. Data analysis using descriptive statistics and 2-way anova. the results showed the significant effect of study time on mathematics learning outcomes with sig $=0,038$. There is significant effect of interest in learning the mathematics learning outcomes with sig $-0,00$. There is no significant effect of the interaction between study time and interest in learning the mathematics learning outcomes with sig $=0,422$.
\end{abstract}

Keyword: Study Time, Interest In Learning, Mathematics Learning Outcomes.

\section{PENDAHULUAN}

Matematika merupakan ilmu universal yang mendasari perkembangan teknologi modern, mempunyai peran penting dalam berbagai disiplin dan memajukan daya pikir manusia. Perkembangan pesat di bidang teknologi informasi dan komunikasi dewasa ini dilandasi oleh perkembangan matematika di bidang teori bilangan, aljabar, analisis, teori peluang dan matematika diskrit. Untuk menguasai dan mencipta teknologi di masa depan diperlukan penguasaan matematika yang kuat sejak dini.

Mata pelajaran Matematika perlu diberikan kepada semua peserta didik mulai dari sekolah dasar untuk membekali peserta didik dengan kemampuan berpikir logis, analitis, sistematis, kritis, dan kreatif, serta kemampuan bekerjasama. Kompetensi tersebut 
diperlukan agar peserta didik dapat memiliki kemampuan memperoleh, mengelola, dan memanfaatkan informasi untuk bertahan hidup pada keadaan yang selalu berubah, tidak pasti, dan kompetitif. Karenanya kegiatan belajar mengajar khususnya dalam matematika perlu lebih diperhatikan lagi mengingat begitu penting matematika bagi siswa nantinya. Menurut Siagian ( 2012: 123), Mata pelajaran matematika merupakan mata pelajaran dasar, di sekolah dasar ataupun seolah menengah, mempelajari matematika adalah penting kareana dalam kehidupan sehari-hari kita tidak boleh mengelak dari aplikasi amtematika bukan itu saja matematika juga mampu mengembangkan kesadaran tentang nilai-nilai yang secara esensial terdapat didalamnya.

Belajar proses mendewasakan diri peserta didik, tujuan ini berlangsung melalui interaksi aktif antara peserta didik dengan guru sebagai pelaksana proses pembelajaran. Belajar memerlukan keterlibatan mental dan kerja aktif peserta didik. Sehingga jelas bahwa kegiatan belajar bukanlah kegiatan sepihak dari guru atau siswa. Keberhasilan belajar sangat bergantung pada keterlibatan menyeluruh antara siswa dibawah bimbingan guru. Kegiatan belajar akan berlangsung optimal jika siswa sebagai peserta didik mengikuti seluruh rangkaian kegiatan secara utuh dan aktif merumuskan setiap temuan.

Belajar matematika juga sangat diperlukan kesiapan peserta didik baik dari lingkungan maupun dari dalam dirinya sendiri, hal ini dikarenakan matematika yang merupakan pelajaran yang tersusun secara sistematis dan membutuhkan penalaran logis, jadi bila proses belajar matematika tidak didukung oleh kedua factor yang berpengaruh tentunya akan memberi kendala pada saat belajar matematika. Berhasil atau tidaknya proses belajar mengajar matematika dapat diukur melalui hasil belajar matematika siswa, jika hasil belajar matematika siswa cenderung baik tentunya memberi pengertian bahwa proses belajar mengajar telah berjalan baik. Dan begitu juga sebaliknya jika hasil belajar matematika mahasiswa cenderung buruk tentunya proses belajar mengajar telah mengalami kendala.

Keberhasilan siswa dalam belajar dapat dipengaruhi oleh factor dari dalam individu maupun luar individu (Siagian, 2012: 123). Banyak hal-hal yang mempengaruhi proses belajar mengajar matematika di sekolah, baik dari luar siswa atau lingkungan maupun dari dalam diri siswa itu sendiri. Ketidaksiapan factor eksternal dan internal akan memberi kendala dalam proses belajar siswa yang kemudian berimbas pada hasil belajar matematikanya.

Faktor dari luar yang sering memberi kendala bagi siswa adalah waktu belajar mereka, di Indonesia ada beberapa sekolah khususnya SD dan SMP yang memiliki perbedaan jam waktu belajar, dikarenakan beberapa alasaan seperti gedung yang belum mampu menampung seluruh siswa sehingga sekolah memberi kebijakan membagi siswa menjadi 2 sesi yaitu sesi 1 pada pagi hari dan sesi 2 pada siang hari. Sedangkan di Perguruan Tinggi perbedaan waktu belajar bukan hal yang baru lagi, mahasiswa harus menerima jadwal yang diberikan oleh kampus, baik pagi, siang atau sore.

Tetapi bukan berarti perbedaan waktu belajar akan memberi dampak buruk bagi peserta didik, karena mungkin saja sekolah dengan kebijakannya sendiri membuat agar siswa tidak bermasalah dengan perbedaan waktu belajar ini, misalnya dengan menerapkan kurikulum yang sesuai dengan kebutuhan.

Beberapa siswa pada umumnya lebih konsentrasi dan fokus saat belajar di pagi hari dengan alasan masih segar sehingga mereka lebih berminat untuk belajar. Sedangkan belajar pada siang hari siswa sudah banyak yang lelah karena telah beraktifitas di pagi hari sehingga sudah kurang berminat lagi pada proses pembelajaran, bahkan ada yang cenderung mengantuk. Tapi tentunya itu tidak semua siswa, ada beberapa siswa yang tidak terpengaruh pada perbedaan waktu belajar ini.Beberapa siswa ada yang lebih suka belajar di siang hari atau di sore hari. 
Sekolah mempunyai kebijakan masig-masing dalam upaya meningkatkan kualitas belajar siswa tentunya dalam hal mata pelajaran matematika, mereka akan beusaha membuat pembelajaran efektif walaupun belajar pada siang hari. Pembelajaran yang menyenangkan dan mampu memberi kebebasan pada siswa untuk mengembangkan ide pribadi akan meningkatkan minat belajar. Dukungan minat belajar sangat dibutuhkan untuk terciptanya pembelajaran efektif. siswa yang pada awalnya tidak mampu menguasai matematika, akan berusaha mengejar ketertinggalannya jika dalam diri siswa terbentuk minat tinggi untuk turut aktif dalam setiap proses pembelajaran, karena ia merasa puas dengan proses belajar.

Dukungan minat belajar secara langsung dapat merubah perilaku belajar, dari tidak peduli menjadi lebih peduli. Yang dengan minat belajar tersebut siswa akan bersedia meninggalkan kegiatan yang kurang mendukung pencapai tujuan belajar. Pengembangan minat belajar tidak akan tumbuh tanpa adanya dukungan faktor pemicu yang mampu mempengaruhi nurani siswa. Faktor pemicu yang dapat berperan mengembangkan minat belajar siswa adalah waktu belajar, jika waktu belajar sesuai maka dapat meningkatkan minat belajar siswa sehingga proses belajar lebih efektif dan dapat meningkatkan hasil belajar matematika.

\section{TINJAUAN PUSTAKA}

\section{Hasil Belajar Matematika}

Pada hakikatnya manusia adalah mahkluk yang berfikir yaitu selalu ingin mengetahui sesuatu baik tentang diri dan lingkungannya melalui panca indera yang dimiliki sesuai dengan perkembangan usianya. Setiap individu akan menjadi dewasa karena belajar dan pengalaman yang dialami sepanjang hidupnya.

Menurut Purwanto (1990: 84), "Belajar terjadi apabila suatu situasi stimulus bersama dengan isi ingatan mempengaruhi siswa sedemikian rupa sehingga perbuatannya (performancenya) berubah dari waktu sebelum ia mengalami situasi itu ke waktu ia sesudah mengalami tadi". Sedangkan Slameto (1995:4) menyatakan bahwa, "belajar adalah suatu proses usaha yang dilakukan seseorang untuk memperoleh suatu perubahan tingkah laku yang baru atau secara keseluruhan sebagai hasil pengalamannya sendiri dalam interaksi dengan lingkungannya."

Adapun definisi lain yang dikemukakan oleh Slameto (1995:13) bahwa, " Belajar adalah suatu proses untuk memperoleh Minat dalam pengetahuan, keterampilan, kebiasaan dan tingkah laku. Belajar adalah upaya memperoleh kebiasaan-kebiasaan, pengetahuan dan sikap-sikap. Upaya yang dilakukan oleh seseorang yang belajaruntuk memperoleh berbagai kebiasaan, ilmu dan sikap di atas dilakukan dengan cara-cara tertentu, sehingga hambatan yang ditemukan dalam proses belajar dapat diatasi, sehingga akan menimbulkan suatu perubahan dalam dirinya dalam mereaksi terhadap situasi belajar yang dialaminya. Bila situasi belajar itu sesuai dengan harapan yang bersangkutan, maka terjadi sedikit banyak perubahan dalam dirinya baik dalam prilaku, tingkah laku maupun psikomotornya."

Menurut Tatan dan Teti (2011:73), "Belajar selalu melibatkan perubahan dalam diri individu seerti kematangan berpikir, berperilaku maupun kedewasaan dalam menentukan keputusan dan pilihan". Hasil belajar yang diperoleh manusia dengan mahkluk lain seperti hewan akan berbeda, pada manusia hasil belajar akan terus mengalami perubahan dan perkembangan, sedangkan pada mahkluk lain tidak mengalami perubahan dan perkembangan secara optimal seperti halnya pada manusia.

Menurut Sudjana (1991:22), "Hasil belajar adalah kemampuan-kemampuan yang dimiliki siswa setelah ia menerima pengalaman belajarnya". Nasution (1994:24) menyatakan bahwa hasil belajar adalah suatu perubahan yang terjadi pada individu yang 
belajar, bukan saja perubahan mengenai pengetahuan, tetapi juga untuk membentuk kecakapan dan penghargaan dalam diri pribadi yang belajar.

Hasil belajar merupakan akibat dari proses belajar seseorang. Hasil belajar terkait dengan perubahan pada diri orang yang belajar. Bentuk perubahan sebagai hasil dari belajar berupa perubahan pengetahuan, pemahaman, sikap dan tingkah laku, keterampilan dan kecakapan. Perubahan dalam arti perubahan-perubahan yang disebabkan oleh pertumbuhan tidak dianggap sebagai hasil belajar. Perubahan sebagai hasil belajar bersifat relatif menetap dan memiliki potensi untuk dapat berkembang.

Suriasumantri (2009:190), "Matematika adalah bahasa yang melambnagkan serangkaian makna dari pernyataan yang ingin kita sampaikan, lambang-lambang matematika bersifat artificial yang baru mempunyai arti setelah sebuah makna diberikan padanya." Semantara itu Suhendri ( 2011: 32 ) menyatakan bahwa matematika adalah ilmu tentang bilangan, bangun, hubungan-hubungan konsep dan logika dengan menggunakan bahasa lambang atau symbol dalam menyelesikan masalh-masalah dalam kehidupan sehari-hari.

Dalam penelitian ini materi pelajaran yang disampaikan adalah operasi bentuk aljabar. Menurut Ruseffendi (1980:148), “ Matematika terdiri dari empat kawasan luas yaitu Aritmetika, aljabar, Geometri dan Analisa. Dimana dalam aritmetika itumencakupantara lain teori bilangan dan statiatika, Aritmetika merupakan cabang matematika yang membicarakan tentang sifat-sifat bilangan dengan dasar-dasar pengerjaan hitung seperti menjumlahkan, mengurangkan,mengalikan dan membagi disebut juga ilmu hitung."

Sedangkan menurut Tampomas (2006: 100), “Aljabar adalah suatu bentuk matematika yang dapat mempermudah masalah-masalah yang sangat sulit dengan menggunakan huruf - huruf'. Pada Aljabar dikenal simbol-simbol abjad seperti a, b, c, x, $y$, dan sebagainya sebagai pengganti bilangan seperti: $x+y, a b, c-d$, dan $x: a$. Dalam perkembangan selanjutnya aljabar tidak hanya menggunakan abjad sebagai lambang bilangan yang diketahui atau yang belum diketahui, tetapi juga menggunakan lambinglambang lain, seperti titik-titik ( contoh: $3+\ldots=5$ ), lebih besar $(>$ ), Lebih kecil $(<)$ dan sebagainya.

Dalam matematika bilangan-bilangan seperti $2 x^{2} y,-10 x$, dan sebagainya disebut bentuk aljabar, Menurut Tampomas (2006:101), “ Bentuk aljabar adalah suatu konstanta, suatu peubah atau suatu bentuk yang melibatkan konstanta dan peubah disertai sejumlah berhingga operasi aljabar".

Dalam matematika, operasi diartikan sebagai pengerjaan (ST Negoro, 2003:218), operasi yang dimaksud adalah operasi hitung atau pengerjaan hitung. Terhadap semua bilangan dapat dilakukan operasi hitung, pada dasarnya operasi hitung mencakup empat pengerjaan dasar yaitu penjumlahan, pengurangan, perkalian dan pembagian. Jadi bila ada kata operasi hitung maksudnya adalah salah satu, beberapa atau semuanya dari penjumlahan, pengurangan, perkalian dan pembagian.

Berdasarkan uraian diatas, disimpulkan bahwa operasi bentuk aljabar adalah operasi hitung yang melibatkan peubah atau variabel meliputi operasi penjumlahan aljabar, pengurangan aljabar, perkalian aljabar, pembagian dan faktorisasi aljabar serta merasionalkan bentuk aljabar.

Berdasarkan uraian dan beberapa teori diatas maka dapat disimpulkan bahwa yang dimaksud dengan hasil belajar matematika adalah pola-pola perubahan tingkah laku seseorang yang meliputi aspek kognitif, afektif, dan psikomotor setelah menempuh kegiatan belajar mengajar matematika yang tingkat kualitasnya sangat ditentukan oleh factor yang ada dalam diri siswa dan lingkungan social yang mempengaruhinya pada 
pokok bahasan operasi bentuk aljabar yang meliputi penjumlahan, pengurangan, perkalian, pembagian dan faktorisasi suku aljabar.

\section{Waktu Belajar}

Belajar suatu proses yang dialami oleh siswa, sukses atau tidaknya proses belajar tersebut tergantung pada banyak factor, salah satu dari sekian banyak factor adalah waktu belajar mereka. Kapan waktu yang tepat untuk belajar dan bagaimana memanfaatkannya agar efektif.

Menurut Tim Penyusun Kamus Pusat Pembinaan dan Pengembangan Bahasa (1996:96), "Kata waktu berasal dari bahasa Arab Waqtu, kemudian diserap ke dalam bahasa Indonesia dan diartikan dengan seluruh rangkaian saat, ketika proses perbuatan berlangsung dan keadaan berada, lamanya kesempatan, atau saat yang ditentukan berdasarkan pembagian bola dunia."

Menurut Siswanto, pada http://www.scribd.com/doc/ 72514700/16/A-DefinisiWaktu " Terminologi waktu banyak digunakan pada beberapa disiplin ilmu diantaranya Ilmu Alam, psikologi dan juga tasawuf. Karena perbedaan objek dan metodenya masingmasing memiliki pemahaman terhadap waktu yang berbeda pula."

Hal ini dapat dijelaskan bahwa waktu merupakan perpindahan-perpindahan simbolik menurut tempat, artinya pergerakan dari satu titik menuju titik lain dalam durasi kemudian kecepatan perpindahan itu diukur dalam satuan waktu. Waktu yang kita kenal dengan jam, hari, bulan dantahun, tidak lebih dari istilah-istilah yang menggambarkan peredaran bumi mengelilingi matahari; atau lebih tepat semua itu merupakan istilah tentang berbagai kedudukan dalam hal tempat. Satu jam peredaran bumi mengitari sumbunya sebesar."

Dari pengertian para ahli ternyata waktu bisa diartikan lebih dari satu pengertian yaitu diartikan sebagai kapan proses itu terjadi dan berapa lama proses itu terjadi. Kedua pengertian ini tentu bisa dihubungkan dengan proses belajar yaitu kapan proses belajar itu terjadi dan berapa lama proses belajar itu berlangsung.

Seperti disebutkan diawal belajar adalah suatu proses dari seorang tidak tahu menjadi tahu, dari tidak bisa menjadi bisa. Tentunya proses tersebut membutuhkan waktu yang tepat agar lebih efektif. Jadi berdasarkan pendapat para ahli diatas, dapat disimpulkan bahwa waktu belajar adalah saat seseorang belajar yang bermakna, jam berapa mereka belajar dan berapa lama mereka mengalami proses belajar ini dari mereka tidak tahu menjadi tahu.

Pagi adalah awal dari hari yang dimulai dari matahari terbit sampai matahari berada tepat diatas bumi. Di sekolah, pagi dimulai dari pukul 6.30 sampai 12.00 , siswa yang bersekolah di sekolah yang mengadakan pembelajaran 2 sesi, waktu belajar pagi akan dimulai pada pukul 06.30 sampai 12.00. Jadi waktu belajar pagi adalah saat dimana seorang siswa belajar bermakna, dari tidak tahu menjadi tahu, dari tidak bisa menjadi bisa yang dilakukan antara pukul 06.30 sampai pukul 12.00. Pagi hari adalah saat dimana suasana masih segar dan tidak panas, sehingga banyak siswa yang lebih memilih belajar pada pagi hari dengan alasan lebih segar sehingga bisa lebih konsentrasi khususnya untuk belajar Matematika.

Siang adalah lawan dari malam. Di sekolah, siang dimulai dari pukul 12.00 sampai 17.30, siswa yang bersekolah di sekolah yang mengadakan pembelajaran 2 sesi, waktu belajar siang akan dimulai pada pukul 12.00 sampai 17.30. Jadi waktu belajar siang adalah saat dimana seorang siswa belajar bermakna, dari tidak tahu menjadi tahu, dari tidak bisa menjadi bisa yang dilakukan antara pukul 12.00 sampai pukul 17.30. Siang hari adalah saat dimana kondisi siswa sudah mengantuk dan lelah karena pada pagi hari sudah beraktifitas ditambah lagi udara sudah panas, sehingga banyak siswa yang sudah tidak 
berkonsentrasi lagi belajar pada siang hari. Tapi seharusnya kendala ini bisa diatasi oleh siswa, karena waktu belajar siang ini bukan pilihan, tapi merupakan keharusan yang harus diikuti oleh siswa.

\section{Minat Belajar}

Hilgard (Slameto,1995:57) menyatakan "interest is persisting tendency to pay attention to end enjoy some activity and content." Lebih lanjut dinyatakan bahwa minat adalah keinginan untuk melakukan suatu kegiatan dalam mencapi sesuatu tujuan.Semakin tinggi keinginan meraih harapan akan semakin kuat pula minat yang mendorong. Sesuai degan kondisi tersebut pula kiranya guru dan orang tua memberi harapan pada anak dalam membangun cita-cita yang mampu mendukung lahirnya minat belajar.

Sardiman (2000:76) menjelaskan minat merupakan suatu kondisi yang terjadi apabila seseorang melihat ciri-ciri atau arti sementara situasi yang dihubungkan dengan keinginan dan kebutuhannya sendiri.

Belajar bersifat aktif, siswa sebagai peserta didik tidak akan mampu merubah perilaku jika ia tidak aktif mengikuti setiap proses yang berlangsung. Efektivitas pembelajaran melekat pada aktivitas belajar dan partisipasi siswa. Untuk dapat bersikap aktif dibutuhkan pula faktor penggerak yang secara langsung memberi dorongan pada siswa untuk bertindak. Faktor pendorong yang dimaksud adalah minat belajar. Dengan tumbuhnya minat belajar, siswa akan berusaha menemukan momen yang tepat dan kondisi yang menarik untuk turut larut dalam proses pembelajaran.

Minat belajar dipengaruhi oleh kesehatan fisik dan kondisi mental (Hapsari, 2007:43). Lebih lanjut dapat dijelaskan, siswa yang kondisi kesehatannya mengalami gangguan tidak akan memiliki keinginan untuk belajar, karena seluruh potensi tubuhnya digunakan untuk menahan rasa sakit yang diderita. Demikian pula dengan kesehatan mental, yang secara langsung akan mengganggu minat belajar. Perasaan benci, sakit hati atau kecewa terhadap guru akan menghambat minat belajar siswa. Tidak jarang siswa enggan belajar matematika, hanya karena ia tidak suka dengan perilaku dan cara mengajar guru matematika. Beberapa siswa menjadi enggan belajar matematika hanya karena guru yang tadinya ia kagumi menegur perilakunya yang kurang baik, atau saat siswa mendapat nilai yang kurang baik dalam ulangan.

Surya (2007:46) menyampaikan beberapa langkah untuk meningkatan minat belajar diantaranya dengan menggugah rasa kebutuhan anak akan pentingnya belajar.Strategi dalam menggugah tentang kebutuhan akan belajar dapat dilakukan dengan membangun dialog dan pendekatan personal, mengembangkan komunikasi kondusif dengan anak. Dalam kontek ini orang tua atau guru sebaiknya tidak hadir dengan mengitervensi atau mendikte tetapi hadir dengan memberi dukungan dan Minat untuk berada pada jalur yang tepat sebagai seorang pelajar.

Hardwinoto dan Setiabudhi (2006:111) menginformasikan bahwa minat siswa terhadap matematika akan bertambah apabila ia dapat memahami dan meyelesaikan soal matematika degan mudah. Seseorang siswa yang mampu memperoleh nilai terbaik dalam ulangan matematika, prestasi tersebut secara langsung akan memberi rasa bangga, yang dengan rasa bangga tersebut terbentuk minat untuk mencapai nilai yang lebih baik, selanjutnya keinginan tersebut akan memacu lahinrnya minat belajar.

Dari definisi dan pengertian diatas dapat disimpulkan bahwa minat belajar merupakan dorongan batin yang tumbuh dari seseorang siswa untuk meningkatkan kebiasaan belajar. Minat belajar akan tumbuh saat siswa memiliki keinginan untuk meraih nilai terbaik, atau ingin memenangkan persaingan dalam belajar dengan siswa lainnya. Minat belajar juga dapat dibangun dengan menetapkan cita-cita yang tinggi dan sesuai dengan bakat dan kemampuan siswa. 
Siswa yang memiliki Minat belajar tinggi akan cenderung tekun, ulet, semangat dalam belajar, pantang menyerah dan senang menghadapi tantangan. Mereka memandang setiap hambatan belajar sebagai tantangan yang harus mampu diatasi. Anak yang berminat belajar tinggi dalam belajar umumnya gemar terhadap Matematika, sehingga mereka belajar Matematika tidak hanya sekedar memenuhi kewajiban dan tugas dari guru atau tuntutan kurikulum, tetapi mereka menjadikan belajar Matematika sebagai suatu kebutuhan yang harus dipenuhi. Bagi mereka, ada atau tidak rangsangan dari luar untuk belajar Matematika tidak ada bedanya.

Siswa yang memiliki tingkat minat belajar rendah, umumnya akan malas belajar, cenderung menghindar dari tugas dan pekerjaan yang berbau Matematika. Akan merasa senang jika guru Matematika tidak hadir, dan tidak ada upaya untuk belajar mandiri menambah pengetahuan baik melalui bertanya pada teman maupun membaca literatur. Jika ada tugas pekerjaan rumah atau tugas lainnya dikerjakan hanya sekedar untuk memenuhi dan menggugurkan kewajiban saja, tidak mempedulikan bahwa tugas tersebut bermakna atau tidak. Siswa yang memiliki minat belajar rendah dibutuhkan peranan guru yang tinggi dalam menyemangati belajar Matematika. Proses pembelajaran Matematika dengan waktu belajar yang sesuai diduga tepat bagi siswa yang berminat belajar rendah. Hal tersebut, karena dalam pembelajaran Matematika dibutuhkan konsentrasi, karena itu dibutuhkan waktu yang sesuai agar proses belajar lebih bermakna.

\section{METODE}

Penelitian ini dilakukan dengan pendekatan kuantitatif, Penelitian ini adalah penelitian Expose Facto. Metode yang digunakan dalam penelitian ini adalah survey. Jenis pengujian yang digunakan adalah Anova Dua Arah. Penelitian dilakukan pada sebuah sekolah yang memiliki dua kelompok waktu belajar yaitu pagi dan siang hari. Masing-masing kelompok waktu belajar dibagi lagi menjadi dua kategori menurut minat belajar, yaitu kelompok yang mempunyai minat belajar kategori tinggi dan kelompok yang mempunyai minat belajar kategori rendah.

Populasi dalam penelitian ini adalah seluruh siswa kelas VIII SMPN yang ada di kecamatan Cipayung. Cara pengambilan sampel dilakukan dengan cluster sampling, teknik cluster sampling dilakukan melalui 2 tahap, yaitu tahap pertama menentukan sampel daerah (kelas), dan tahap berikutnya menentukan orang-orang yang ada pada daerah (kelas) itu secara sampling pula. Sesuai dengan itu maka pada penelitian ini penentuan sampel juga dilakukan melalui 2 tahap, sebagai berikut:

a. Tahap pertama

Pengambilan kelas untuk kelompok eksperimen dan kelas kontrol dilakukan dengan teknik cluster random sampling (sampel acak kelas). Hal ini berdasarkan pertimbangan karena 1 sekolah maka data yang ada bersifat homogen (setara).. Karena di SMPN 246 kelas VIII terdiri dari 4 kelas dengan 2 kelas yaitu kelas VIIIA dan VIII-B belajar dengan waktu belajar pagi dan 2 kelas lainya yaitu VIII-C dan VIII-D belajar dengan waktu belajar siang, maka pengambilan sampel kelas dilakukan dengan cara mengundi seperti sistem arisan kocokan pertama terdiri dari kelas VIII-A dan kelas VIII-B nama kelas yang keluar pada kocokan pertama yaitu dijadikan sebagai kelas eksperimen, kocokan kedua terdiri dari kelas VIII-C dan VIII-D, nama kelas yang keluar pada kocokan kedua sebagai kelas control.Ternyata pada pengocokan pertama kelas VIII-A yang keluar, pengocokan kedua kelas VIIID. Dengan demikian yang menjadi kelas eksperimen adalah kelas VIII-A, kelas kontrol adalah kelas VIII-D. 
b. Tahap kedua

Pengambilan sampel individu dilakukan dengan teknik sampling sistematis. Dalam hal ini sampel individu diambil berdasarkan urutan skor skala minat yang diperoleh berdasarkan tes minat belajar. Peneliti mengambil 13 urutan skor teratas sebagai kelompok siswa berminat belajar tinggi, dan 13 urutan skor terbawah sebagai kelompok siswa yang berminat belajar rendah dari kelas eksperimen dan juga kelas kontrol. Dengan demikian diperoleh 4 kelompok sampel penelitian yaitu: 13 siswa berminati belajar tinggi yang belajar pada waktu belajar pagi, 13 siswa berminat belajar tinggi yang belajar pada waktu belajar siang, 13 siswa berminat belajar rendah yang belajar pada waktu belajar pagi, dan 13 siswa bermotivasi belajar rendah yang belajar pada waktu belajar siang.

\section{HASIL DAN PEMBAHASAN}

\section{Analisis Deskriptif}

Dari hasil perhitungan diperoleh data skor hasil belajar matematika untuk kelompok sampel yang belajar pada siang hari memiliki rata-rata 14,85; median 14 ; modus 14 ; varians 19,08 dan simpangan baku 4,36. Dapat disimpulkan bahwa hasil belajar kelompok ini cukup baik. Sedangkan data skor hasil belajar matematika untuk kelompok sampel yang belajar pada pagi hari memiliki rata-rata 17,07 ; median 17 ; modus 18 ; varians 14,37 dan simpangan baku 3,9. Dapat disimpulkan bahwa hasil belajar kelompok ini cukup baik.

Data skor hasil belajar matematika untuk kelompok sampel yang minat tinggi memiliki rata-rata 17,9; median 19 ; modus 21 ; varians 20,3 dan simpangan baku 4,5. Dapat disimpulkan bahwa hasil belajar kelompok ini cukup baik. Sedangkan data skor hasil belajar matematika untuk kelompok sampel yang memiliki minat rendah memiliki rata-rata 14 ; median 14 ; modus 13; varians 8,69 dan simpangan baku 2,95. Dapat disimpulkan bahwa hasil belajar kelompok ini cukup baik.

Data skor hasil belajar matematika untuk kelompok sampel yang minat tinggi dan belajar pada siang hari memiliki rata-rata 16,38 ; median 18 ; modus 10 ; varians 24,08 dan simpangan baku 4,91. Dapat disimpulkan bahwa hasil belajar kelompok ini cukup baik. Sedangkan data skor hasil belajar matematika untuk kelompok sampel yang memiliki minat rendah dan belajar pada waktu siang hari memiliki rata-rata 13,3; median 12 ; modus 13 ; varians 10,8 dan simpangan baku 3,28. Dapat disimpulkan bahwa hasil belajar kelompok ini cukup baik.

Data skor hasil belajar matematika untuk kelompok sampel yang minat tinggi dan belajar pada pagi hari memiliki rata-rata 19,46; median 21;modus 21 ; varians 11,78 dan simpangan baku 3,43. Dapat disimpulkan bahwa hasil belajar kelompok ini cukup baik. Sedangkan data skor hasil belajar matematika untuk kelompok sampel yang memiliki minat rendah dan belajar pada waktu pagi hari memiliki rata-rata 13,69 ; median 14 ; modus 13 ; varians 15,59 dan simpangan baku 2,36. Dapat disimpulkan bahwa hasil belajar kelompok ini cukup baik.

\section{Uji Persyaratan Analisis Data}

Data yang telah dikumpulkan kemudian diuji persyaratan analisis, meliputi uji normalitas dan uji homogenitas. Hasil pengujian normalitas menggunakan uji liliefors diperoleh hasil seluruh kelompok data hasil belajar matematika berdistribusi normal. Sedangkan pengujian homogenitas menggunakan uji Bartlett diperoleh hasil bahwa seluruh kelompok sampel data hasil belajar matematika adalah bersifat homogen. 


\section{Uji Hipotesis Penelitian}

Tujuan dari penelitian ini adalah untuk mengetahui perbedaan rata-rata skor dengan dua variabel bebas.

Analisis data untuk menguji hipotesis pada penelitian ini melalui teknik analisis of varians (ANOVA) dua jalur yang dilakukan secara komputerisasi melalui program SPSS 16 dan rangkumannya terlihat dalam tabel 1 .

Tabel 1. Hasil Uji Hipotesis

Tests of Between-Subjects Effects

Dependent Variable:Hasil Belajar

Matematika

\begin{tabular}{|c|c|c|c|c|c|}
\hline Source & $\begin{array}{c}\text { Type III Sum } \\
\text { of Squares }\end{array}$ & Df & Mean Square & F & Sig. \\
\hline Corrected Model & $274.077^{\mathrm{a}}$ & 3 & 91.359 & 6.450 & .001 \\
Intercept & 13248.077 & 1 & 13248.077 & 935.370 & .000 \\
A & 64.692 & 1 & 64.692 & 4.568 & .038 \\
B & 200.077 & 1 & 200.077 & 14.126 & .000 \\
A * B & 9.308 & 1 & 9.308 & .657 & .422 \\
Error & 679.846 & 48 & 14.163 & & \\
Total & 14202.000 & 52 & & & \\
Corrected Total & 953.923 & 51 & & & \\
\hline
\end{tabular}

a. $\mathrm{R}$ Squared $=.287$ (Adjusted R Squared $=.243$ )

Berdasarkan Tabel 1 dapat disimpulkan:

a. Pengujian Hipotesis 1:

Dari pengujian dengan SPSS 16 diatas didapat sig untuk waktu belajar (A) adalah $0,038<0,05$ dengan demikian dapat disimpulkan terdapat pengaruh waktu belajar yang signifikan terhadap hasil belajar matematika.

b. Pengujian Hipotesis 2:

Dari pengujian dengan spss 16 diatas didapat sig untuk minat belajar adalah $0,00<$ 0,05 dengan demikian dapat disimpulkan artinya terdapat pengaruh minat belajar yang signifikan terhadap hasil belajar matematika.

c. Pengujian Hipotesis 3:

Dari pengujian dengan SPSS 16 diatas didapat sig untuk waktu belajar dan minat $0,422>0,05$ dengan demikian dapat disimpulkan tidak terdapat pengaruh interaksi yang signifikan anatara waktu belajar dan minat belajar terhadap hasil belajar matematika.

\section{Pembahasan}

Berdasarkan hasil penelitian terbukti terdapat pengaruh yang signifikan antara waktu belajar terhadap hasil belajar matematika. Hal ini menunjukan hasil belajar matematika akan meningkat bila siswa belajar pada waktu pagi hari. Materi pelajaran matematika yang sulit dan membutuhkan konsentrasi dalam mempelajarinya membutuhkan waktu yang tepat dalam belajar, kondisi waktu pagi hari yang masih segar karena belum banyak beraktifitas membantu siswa konsentrasi dalam belajar matematika, hal ini menyebabkan hasil belajar matematika meningkat. Bahwa waktu memang berpengaruh terhadap keberhasilan belajar seseorang (Hakim, 2005:20) seorang siswa 
akan dapat mencapai keberhasilan dalam belajar, jika ia memiliki waktu yang tepat untuk belajar dan bisa mengatur waktu tersebut agar lebih efisien sehingga proses pembelajaran lebih efektif.

Selain faktor eksternal yang mempengaruhi hasil belajar matematika siswa, terdapat juga factor internal yang juga mempengaruhi tingkat hasil belajar matematika siswa yaitu minat belajar. Dari hasil penelitian dapat dilihat bahwa terdapat pengaruh yang signifikan antara minat belajar terhadap hasil belajar matematika. Hal ini menunjukan siswa yang memiliki minat tinggi memiliki hasil belajar matematika yang lebih baik. Minat belajar siswa dapat meningkatkan hasil belajar matematika karena jika siswa senang dengan pelajaran matematika maka siswa tersebut akan memotivasi dirinya sendiri untuk belajar dengan baik sehingga mendapatkan hasil belajar yang sangat memuaskan. Hal ini senada dengan Tatan (2011: 80) yang menyatakan bahwa terdapat pengaruh minat belajar terhadap hasil belajar Matematika.

Waktu belajar yang berpengaruh pada hasil belajar matematika dan minat belajar yang juga berpengaruh pada hasil belajar matematika ternyata tidak berarti bahawa keduanya secara bersama-sama akan mempengaruhi hasil belajar Matematika. hal ini didasarkan pada hasil penelitian yang menyebutkan bahwa tidak terdapat pengaruh interaksi waktu belajar dan minat belajar terhadap hasil belajar matematika.

Seseorang dengan minat belajar yang tinggi tidak akan menjadikan hambatan sebagai halangan atau kendala dalam belajar, mereka yang berminat tinggi tidak akan mengalami kendala dalam belajar di waktu kapanpun baik pagi maupun siang, begitupula dengan mereka yang minat belajarnya rendah, walaupun mereka belajar di pagi hari tidak mempengaruhi hasil belajar matematika mereka. Hal ini menyebabkan tidak terdapat interaksi yang signifikan antara waktu belajar dan minat belajar terhadap hasil belajar matematika. Karena itulah untuk meningkatkan hasil belajar Matematika siswa akan lebih efektif dengan meningkatkan minat belajar mereka, karena dengan minat belajar tinggi akan membuat siswa semangat belajar dan tidak menjadikan hambatan sebagai suatu masalah melainkan menjadikan tantangan, sehingga hasil belajar matematika siswa akan lebih baik denagan kendala waktu belajar yang berbeda.

\section{PENUTUP}

\section{Kesimpulan}

1. Terdapat pengaruh yang signifikan waktu belajar terhadap hasil belajar Matematika siswa.

2. Terdapat pengaruh yang signifikan minat belajar terhadap hasil belajar Matematika siswa.

3. Tidak terdapat pengaruh interaksi yang signifikan antara waktu belajar dan minat belajar terhadap hasil belajar Matematika siswa.

\section{Saran}

Berdasarkan kesimpulan dan implikasi penelitian maka beberapa saran terkait yang dapat penulis sampaikan pada penelitian ini adalah:

1. Waktu belajar yang tepat bagi siswa adalah di waktu pagi, karenanya bagi sekolah yang masih menerapkan waktu belajar di siang hari sekiranya mampu memberikan cara belajar yang sesuai dengan kondisi waktu belajarnya. Misalnya dengan menerapkan metode pembelajaran yang menyenangkan dan variatif sehingga siswa lebih berminat untuk belajar Matematika. Karenanya bagi guru diperlukan pengembangan pembekalan teori-teori, konsep-konsep dan aspek-aspek yang dimiliki guru yang berhubungan dengan mata pelajaran Matematika. 
2. Diperlukan kerjasama antara pemerintah dan pihak sekolah agar dapat mengusahakan pelaksanaan kegiatan belajar mengajar pada satu sesi saja yaitu pagi hari, karena untuk merealisasikannya sangat dibutuhkan biaya dan tenaga yang tidak bisa hanya diselesaikan oleh pihak sekolah saja.

3. Perlu dilakukan penelitian lebih lanjut tentang efektivitas waktu belajar dan minat belajar siswa, serta analisis terhadap faktor-faktor psikologis lainnya yang diperkirakan sangat besar pengaruhnya pada hasil belajar Matematika siswa untuk materi atau pokok bahasan serta tingkat pendidikan lainnya.

\section{DAFTAR PUSTAKA}

Hakim, Thursan. 2005. Belajar Secara Efektif. Jakarta: Pustaka Pembangunan Swadaya Nusantara.

Hapsari, Sri. 2007. Bimbingan dan Konseling. Jakarta: Grasindo.

Hardwinoto dan Setiabudhi. 2006. Anak Unggul Berotak Prima. Jakarta:Gramedia.

Nasution. 1994. Didaktika Azas-azas Mengajar. Bandung: Jemars.

Negoro, ST B.Harahap. 2003. Ensiklopedia Matematika. Jakarta: Ghalia Indonesia.

Purwanto, Ngalim. 1990. Psikologi Pendidikan. Bandung: Remaja Rosdakarya.

Ruseffendi, ET. 1980. Pengajaran Matematika Modern Untuk Orangtua, Murid, Guru dan SPG. Bandung: Tarsito.

Sardiman. Interaksi dan Minat Belajar Mengajar, Jakarta: CV. Rajawali. 2000.

Siagian, Roida. 2012. Pengaruh minat dan kebiasaan belajar terhadap prestasi belajar matematika. Jurnal Formatif, 2(2): 122-131.

Siswanto, Joko. 2011. Definisi Waktu Belajar. www.scribd.com/doc/7251470 0/16/A-. Definisi-Waktu. 13 Juni 2012

Slameto. 1991.Belajar dan Faktor-faktor yang Mempengaruhinya, Jakarta: Rineka Cipta.

Sudjana, Nana. 1991.Penelitian Hasil Proses Belajar Mengajar. Bandung: Remaja Rosdakarya.

Suhendri, H. 2011. Pengaruh kecerdasan matematis-logis dan kemandirian belajar terhadap hasil belajar matematika. Jurnal Formatif, 1 (1): 29-39.

Suriasumantri, Jujun S. 2009.Filsafat Ilmu (Sebuah Pengantar populer). Jakarta: pustaka Sinar harapan.

Surya, Hendra. 2007. Percaya diri Itu Penting.Jakarta: Elex Media Komputindo.

Tampomas, Husein. 2006.Matematika Plus 1A. Jakarta: Yudhistira.

Mutakin, T.Z. dan Teti Sumiati. 2011. Pengaruh penggunaan media belajar dan minat belajar terhadap hasil belajar matematika. Jurnal Formatif, 1 (1): 70-81.

Tim Penyusun. 1996. Kamus Pusat Pembinaan dan Pengembangan Bahasa. Jakarta: DEPDIKNAS. 